techniques of sports training, the system of training athletes in technical and aesthetic sports, the basic laws of the learning process and the improvement of physical exercise techniques in difficult coordination sports, training and competitive features in cheerleading, features of the cheerleading performance of various functions in the competitive process, and previous studies on the place and importance of technical training in the training process of young chelle athletes Irova in step preliminary base preparation and baseline technical and physical fitness of athletes-cherlidirov.

The experimental methodology covers three levels of technical training for which the goals and objectives of training are separately defined, the own means and methods of sports training and were planned in accordance with the structure of two-cycle summer training taking into account the assigned tasks of the mesocycle.

Cheerleading sports training is built as a year-round process that has certain time intervals for solving the main tasks of the educational process. The priority of the cheerleaders is technical training, since the main criterion for evaluating the performance of a team in competitions is the quality and complexity of the technical elements. The methodology for improving the technical training of cheerleaders of 9-12 years at the stage of preliminary basic training is substantiated. It was established that the annual cycle of training young cheerleaders at the stage of preliminary basic training has a two-cycle macrostructure. Bringing up skills of maximum manifestation of forces and the realization of motor potential during the performance of the overall composition, achievement of stability and variability of the competitive composition, which forms the basis of general activity, cheerleader athletes go to a new level of preparedness.

Keywords: cheerleading, cheerleading base, cheerleading flyers, technical training, technical readiness, the stage of preliminary basic training, improvement, technique.

DOI: https://doi.org/10.31392/NZ-npu-142.2019.10

УДК 378[37.018+78]

Економова О. С., Гаркуша Л. І.

\title{
ЕСТЕТИЧНЕ СПРИЙНЯТТЯ ФОРТЕПІАННИХ ТВОРІВ У ПІДГОТОВЦІ СТУДЕНТІВ ДО ПРАКТИЧНОЇ ДІЯЛЬНОСТІ
}

В умовах оновлення парадигми мистеиької освіти особлива увага приділяється професійній підготовиі майбутнього вчителя, розвитку виконавської майстерності. Стаття присвячена обтрунтуванню прочесу розвитку творчої особистості в умовах творчоестетичного напрямку профільного навчання. Представлено зміст навчання учнів, що проявляється у педагога мистецьких дисциплін як особистості і як суб’єкта діяльності, в процесі здійснення профільної освіти. В статті розкриваються сутність та характерні риси підходу до проблеми підбору музичного репертуару, щүо має велике значення в педагогізачії навчального прочесу як вагомого чинника формування творчої особистості майбутнього вчителя музики. У статті визначена взасмозалежність особистостей процесу фахової підготовки майбутніх вчителів музичного мистецтвва та наявності в них умінь професійної самореалізації та підбору репертуару, який спрямований на розвиток піаністичних здібностей, формування художнього смаку та художніх иүінностей, в основі яких лежать такі принципи як художня цінність, естетична значущість художніх творів, доступність до виконання, педагогічна доиільність, тематичне, жанрове та стильове різнобарв'я. Серед завдань формування творчого потенціалу студентів є формування художньо-естетичних поглядів, професійної майстерності студентів, досконало підібраний музичний матеріал, який 
спрямовує його музично-історичні та музично-теоретичні знання.

У статті показано особливості підготовки вчителя музики до організаиії профільного навчання художньо-естетичного напряму та шляхи творчого розвитку особистості в умовах інноваційних змін в освіті.

Відроджуючи національну школу, окрему увагу слід приділити фортепіанній музиці тих украйнських композиторів, творчість яких звернена безпосередньо до дитячої аудиторії, адже разом із дитячою музикою закладаються підвалини наиіональної свідомості.

Ключові слова: художньо-естетичний напрям, педагог мистецьких дисциплін, парадигма мистецької освіти, музичний репертуар, професійна підготовка.

Слухання музики - це найважливіший аспект музичного виховання студентів, оскільки без нього не може здійснюватися жодна музична діяльність, у тому числі і навчання музики. Завдяки різноманітності методів і фрорм знайомство із творами різних жанрів і композиторів сприяє розширенню музичного світогляду студентів, виховання у них музичного смаку. У процесі слухання фрормуються навички музичного мислення, уміння емоційно та свідомо сприймати музичну тканину, накопичується музично-слуховий досвід.

Б. Асаф'єв, який приділяв багато уваги проблемі викладання музики у школі, писав про те, що “спостереження музики передусім веде до загострення слухових вражень, отже, до збагачення нашого життєвого досвіду та нашого знання про світ через слух".

Mema cmammi - показати особливості підготовки вчителя музики до організації профільного навчання художньо-естетичного напряму та шляхи творчого розвитку особистості в умовах інноваційних змін в освіті.

При вирішенні завдання активізації і навчальної діяльності велика роль належить вчителю. Як для загального музичного розвитку, так і для розвитку окремих музичних здібностей одним із найважливіших завдань викладача в роботі зі студентами є визначення сформованості їхнього музично-слухового багажу й опора як на нього, так і на досвід їхніх емоційних вражень, та емоційно-естетичний розвиток, який досягається внаслідок розвитку музичного.

Розвиток у студентів здатності до сприйняття естетичних властивостей форми художнього твору передбачає створення певних умов. Важливо враховувати, що студенти з різною підготовкою, з різною естетичною реакцією будують власні художньо-структурні узагальнення на різних рівнях сприйняття, по-своєму охоплюють фрормотворчі зв'язки, їх взаємопроникнення. Отже, піклування про емоційне забарвлення сприйняття не може оминути опору на індивідуальні властивості художнього ставлення студента до музики. Важливою умовою розвитку у студентів естетичних орієнтирів сприйняття музичної форми слід визначити первісну орієнтацію їхньої уваги на осягнення краси звуку, інтонації, мелодії, і вже потім на з'ясування художнього навантаження, поступово переростати в узагальнення мовно-стильових, жанрових характеристик творчості композиторів, певної школи та художнього напрямку.

Музичне сприйняття припускає наявність у людини певних музичноестетичних здібностей, навичок і знань, які дають можливість об'єктивно-творчо сприймати втілені в музичних образах явища навколишньої дійсності, відтвореної у музичній образності, на основі загально-художнього освоєння засобів художньої виразності. 
Становлення естетичних критеріїв у студентів передбачає не тільки широке, а й багаторазове сприймання музики на слух. При такому підході розширюється коло охоплених в естетичній свідомості деталей, непомічене раніше стає очікуваним, бажаним. Повторюваність слухання тих самих творів активізує процес охоплення характерних ознак стилю, робить більш рельєфним сприйняття конкретних деталей. Разом 3 тим, у студентів зберігається невимушеність естетичних переживань, їх безпосередність, оминається сухий академізм у сприйманні.

I звичайно, прогрес у розвитку музичного сприйняття безпосередньо залежить від розвитку музичних здібностей. Вірно організований процес систематичного слухання музики сприяє розвитку музично-художнього слуху, музично-естетичних здібностей. Прослуховування музики має ще й ті переваги, що дає змогу не тільки охопити велику кількість творів певного композитора і тим самим розширити діапазон музично-естетичних переживань формотворчих структур, а й співвіднести індивідуальні особливості сприймання студента із музично-естетичними цінностями музичного репертуару.

Робота над стильовими особливостями композиторської творчості зумовлюється не лише необхідністю професійно-фахового заглиблення в особливості художнього почерку композитора, а й тим впливом на активізацію естетичного переживання, яке може справити тільки практично-творча робота над музичним твором. Відчуття естетичних достоїнств музики, що виникає під пальцями, підносить на вищий щабель її сприйняття, відкриває студентам шлях до осягнення не тільки поверхових, а й внутрішніх глибинних ознак краси художньої фрорми. При виконавському опрацюванні естетичні переживання окремих художніх структур та їх деталей доповнюються проникненням у їх взаємозв'язок, у цілісність композиторського стилю. Емоційне-образне, почуттєве осягнення музики повинно бути у своїй основі первісним. Тобто професійною якістю вчителя музики повинне бути вміння спрямувати франтазію, пам'ять, силу уяви студента, залучити до участі у сприйнятті музики асоціативну сореру його мислення шляхом раціонально-логічного підходу.

Словесна характеристика музичного твору $€$ одним із найважливіших інструментів у навчанні музики. Цей метод дає змогу перейти від пасивного сприйняття до активного слухання, сформувати у студента ставлення до музики як до емоційно-змістовної мови, а не як до суто акустичного явища. Надати студентам можливість зрозуміти мову музики, знайти у ній ті виражальні й зображальні моменти, які $є$ найбільш цікавими та привабливими для особистості людини і співвідносяться 3 їі особистим досвідом - ось основне завдання майбутнього учителя музичного мистецтва у школі.

В умовах національно-культурного відродження важливим чинником музично-естетичного виховання студентів $\epsilon$ осмислення та використання кращих надбань національної музичної культури, духовності рідного народу, його національних традицій і звичаїв. Це сприяє успішному фрормуванню у молоді національної самосвідомості.

Особливої актуальності набуває проблема реалізації естетико-виховного потенціалу української музики при практичній роботі студентів на уроках музики в загальноосвітній школі. Педагогічна доцільність її використання обумовлюється художньою довершеністю, самобутністю музичної мови, 
національно-стильовими та жанровими ознаками.

Насамперед слід відмітити необхідність уже в навчальному закладі поставити студента в умови, наближені до умов їх майбутньої практичної роботи. Зрозуміло, що на різних етапах навчання ступінь цього наближення буде різною: на перших курсах - меншою, а на останніх - більшою. Ще М. Римський-Корсаков писав: “Практика $є$ кращий засіб навчитися. Головне, необхідно створити в консерваторії практичне музичне життя, наближене до життя дійсності".

Пошук нових шляхів наближення навчального процесу до практичної діяльності продовжується і за нашого часу. Практика студентів здійснюється в різних формах. Мета педагогічної практики - навчити молодого музиканта займатися з учнями. Але в цій вузькій робочій меті $є$ ще один важливий бік: студенти послідовно ставлять перед своїми учнями музичні завдання, пояснюють їх, показують засоби подолання різних труднощів. Відтак студент більш відповідально ставиться і до процесу своїх особистих повсякденних занять.

Обмеження професійної підготовки тільки моделюванням майбутньої практичної діяльності не може сьогодні задовольнити педагогіку вищої школи. Моделювання - необхідний, проте далеко не достатній підхід до підготовки педагога-музиканта. Професіоналізація без залучення студентів до практичної роботи в реальних умовах виявляється обмеженою, звуженою, а в низці випадків навіть дезорієнтуючою.

Наприклад, вчорашній випускник вибудовує модель бесіди про музику, виходячи з абстрактних, а часом застарілих уявлень про естетичні потреби школярів. У підсумку зустріч із реальною аудиторією, із запитами сучасної української молоді виявляється невдалою. Забезпечення студентів можливістю реального спілкування з дітьми виявляється дійовим стимулом до розкриття їх творчого потенціалу. Практична діяльність у реальних обставинах у процесі навчання у виші $є$ чинником опосередкованого спонукання майбутніх фахівців до творчого саморозкриття, до музично-педагогічної самореалізації.

Д. Кабалевський: “Значення музики у школі далеко виходить за межі мистецтва. Разом з літературою та образотворчим мистецтвом музика рішуче втручається в усі галузі виховання, освіти і стає могутнім засобом формування духовного світу особистості".

Програма пропонує широкі можливості для творчого пошуку студента при роботі у школі. Хороший сучасний урок музики - це свого роду педагогічний твір, котрий зароджується у процесі творчості, де натхнення та копітка праця єдині.

На сучасному етапі, коли молодь захоплюється дешевими пісеньками без мелодії та тексту, вчитель музики весь час повинен бути в пошуку таких фрорм навчання та виховання, завдяки яким усі ланки музично-естетичного процесу, види діяльності з'єднаються в єдиний потік становлення людини. На такому занятті все важливо: і вдало обрана тема, і розподіл музично-теоретичного матеріалу, і вибір потрібних прийомів впливу на емоційний світ учня, його музичний розвиток. Учитель, готуючись до уроку, повинен поставити собі запитання, а потім знайти відповіді:

1. Чому він повинен навчити учнів на цьому занятті? 
2. Як допоможе навчальний матеріал розвивати вміння та навички?

3. Як музичні твори впливають на погляди, переконання, почуття учнів?

4. Який внесок зробить цей урок у процес музично-естетичного виховання учнів?

Підготовка студентів до педагогічної практики передбачає роботу над шкільним репертуаром та оволодіння шкільною програмою з музики. Вивчення шкільного репертуару треба розглядати не тільки як спосіб накопичення його, але і як оволодіння методами та прийомами практичної роботи у школі. На цьому матеріалі викладач може вирішувати питання загальної організації студентів, розвивати самостійність, використовуючи легкі твори для самостійного вивчення студентами, а також, виховувати виконавські навички.

Відроджуючи національну школу, окрему увагу слід приділити фортепіанній музиці тих українських композиторів, творчість яких звернена безпосередньо до дитячої аудиторії, адже разом із дитячою музикою закладаються підвалини національної свідомості. Кожен рік із друку виходить чимало збірників зовсім нової музики для дітей та юнацтва. У них зустрічаються справжні перлини - яскраві образні п'єси, придатні захопити і слухача, і виконавця. П'єси для дітей Р. Верещагина, В. Клина, О. Некрасова, В. Підвали та ін.; дитячі фортепіанні альбоми Л. Колодуба, В. Бібіка, В. Кирейка, М. Заморокко, В. Губи, О. Костіна, М. Кармінського складають цілий світ дитини. Завдання викладача - активніше залучати у процес музичноестетичного виховання твори цих композиторів, які поруч із українською класикою та народною творчістю будуть закладати підвалини становлення національної свідомості та самосвідомості.

\section{Використана література:}

1. Гольденвейзер А. Б. Искусство и творческие способности. Москва : Музыка, 1976. С. 93-130.

2. Гуральник Н. Українська фортепіанна школа в контексті музичної педагогіки. Вища школа, 2007. $312 \mathrm{c.}$

3. Гинзбург Л. С. О работе над музыкальными произведениями : метод. очерк. Музыка. 1968. 112 с.

4. Коган Г. Н. Работа пианиста. Музыка. 1979. 182 с.

5. Савшинский С. И. Работа пианиста над музыкальным произведением. Музыка. 1964. 186 с.

\section{Ref erences:}

[1] Goldenvejzer, A . B. (1976). Iskusstvo i tvorcheskie sposobnosti. M oskva : M uzyka, S. 93-130.

[2] Huralnyk, N. (2007). Ukrainska fortepianna shkola v konteksti muzychnoi pedahohiky. Vyshcha shkola, $312 \mathrm{~s}$.

[3] Ginzburg, L. S. (1968.). 0 rabote nad muzykalnymi proizvedeniyami : metod. ocherk. M uzyka. $112 \mathrm{~s}$.

[4] Kogan, G. N. (1979). Rabota pianista. M uzyka. $182 \mathrm{~s}$.

[5] Savshinskij, S. I. (1964). Rabota pianista nad muzykalnym proizvedeniem. M uzyka. $186 \mathrm{~s}$.

ЭКоНомова О.С., ГАРКУШАЛ.И. Эстетическое восприятие фортепианных произведений при подготовки студентов к практической дуятельности.

В статье рассматривается проблема самореализаџии личности в условиях обновления парадигмы образования. Определена взаимосвязь особенностей процесса профессиональной подготовки будущих учителей музыки и наличие у них умений профессиональной самореализачии, которые направлень на развитие пианистических способностей, формирование эстетического вкуса и художественных ценностей. Раскрываются педагогические методы и актуальность в подборе материала, что способствует 
гармоничному развитию личности. Дается обоснование прочесса развития творческой личности в условиях художественно-эстетического направления профильного обучения. Цель работы - воспитание у студентов навыков самостоятельности, творческого подхода, ознакомление с методами работы над новыми произведениями, которые формируют художественно-эстетические взгляды, профессиональное мастерство студента, методически грамотно подобранный материал, углубляющиий музыкально-эстетические и музыкальнотеоретические знания.

В статье показаны особенности подготовки учителя музыки к организации профильного обучения художественно-эстетического направления и пути творческого развития личности в условиях инновачионных изменений в образовании. Возрождая национальную школу, особое внимание следует уделить фортепианной музыке украинских композиторов, творчество которых обращено непосредственно к детской аудитории, ведь вместе с детской музыкой закладываются основы наџионального сознания.

Ключевые слова: парадигма музыкального образования, педагогический репертуар, профессиональная подготовка, профессиональная самореализаиия, музыкально-эстетическое направление.

Ekonomova O. S., GarkUSHA L. I. Aesthetic approach forthety creatives in preparation of students for practice activities.

The article is devoted to the substantiation of the development process of a creative individual in the conditions of creative and aesthetic direction of profile education. The content of teaching of students is presented, which is shown in the teacher of artistic disciplines as a person and as a subject of activity, in the process of profile education. The article reveals the essence and features of the approach to the problem of the selection of musical repertoire, which is of great importance in the pedagogy of the educational process as a significant factor in the formation of the creative personality of the future teacher of music. The article defines the interdependence of the personalities of the process of professional training of future teachers of musical art and the presence of skills in their professional self-realization and selection of repertoire aimed at the development of piano skills, the formation of artistic taste and artistic values, based on such principles as artistic value, aesthetic significance of artistic works, accessibility to performance, pedagogical expediency, thematic, genre and style of colorfulness. The work on musical material is intended to ensure the systematic preparation of students for teaching practice and mastering the musical program of music. Among the tasks of forming the creative potential of students is the formation of artistic and aesthetic views, professional skills of students, competently selected musical material, which directs its musicalhistorical and musical-theoretical knowledge. The purpose of the article is to educate students about the skills of autonomy, creative approach, aesthetic taste, familiarization with the methods of working on the new software musical works of Ukrainian composers. Bring the student to the understanding of the importance of professional mastering the piano and the best mastery of piano literature - a concrete and accessible purpose of the learning process of mastering the course of the piano.

Keywords: artistic-aesthetic direction, teacher of artistic disciplines, paradigm of artistic education, musical repertoire, professional training. 